\title{
THE FUTURE OF BIRCH FROM THE VIEWPOINT OF THE VENEER INDUSTRY ${ }^{1}$
}

\author{
BY J. E. BOTHWELL 2
}

When I was asked to take part in this panel on "The Future of Birch in Canada in Canada" I naturally assumed we were thinking of yellow birch; but as I got deeper into the subject I began to wonder if much of the future didn't possibly lie in white birch.

The Forest Resources Inventory Report No. 11 put out by the Ontario Department of Lands and Forests for the Sault Ste. Marie District shows that, of the mature yellow birch, $93 \%$ is in the 10-inch-and-over size class whereas of the immature yellow birch, $88 \%$ is in this same class. This means that only $12 \%$ of the yellow birch volume in the immature age class is available as a source of yellow birch for the future.

In the immature age class white birch and poplar have replaced yellow birch and maple as the principal hardwood species.

The last remaining stands of yellow birch in Canada are in the AlgomaSault Ste. Marie area, the Upper Ottawa Valley and Central Quebec. The demand for hardwood veneer in Canada is increasing each year, and with the anticipated growth of the country this upward trend is more apt to continue.

In addition to our own needs there is a great demand from the United States. According to the brief presented by the Canadian Hardwood Veneer and Plywood Association to the United States Tariff Commission in March, $1955,80 \%$ of the yellow birch in the form of logs or veneers needed by the United States Plywood Industry was supplied by Canada.

Present mills have expanded and are expanding for more production, and smaller mills are being established to meet this demand.

A study of inventory and the cutting pressures in the two principal yellow birch and maple areas in Ontario will show just how this demand is affecting our stands.

In the South Central Region, that is, Parry Sound, Algonquin Park, etc., birch represents approximately $31 \%$ of the total gross volume while maple constitutes approximately $27 \%$. In this region during the period 1948 1952 the figures for the average annual cut show that birch made up 24\% of the total cut while maple amounted to only approximately $7 \%$.

For the Sault Ste. Marie region the story is much the same. The inventory shows birch and maple each making up around $20 \%$ of the total gross volume; but for the year ending March 31, 1954 yellow birch accounted for $19.5 \%$ of the cut while maple was only $5 \%$.

This clearly indicates that yellow birch is the desirable species, and under the present conditions, an enormous drain is being made on these remaining

$\overline{\mathbf{z}}$ Paper presented at the $48 \mathrm{th}$ Annual Meting of the Canadian Institute of Forestry in Chicoutimi, Que., October 2nd to 5th, 1956.

${ }^{2}$ Chief Forester, Roddis Lumber \& Veneer Co. of Canada Ltd., Sault Ste. Maric, Ontario. 
tands. If we hope to prolong their life we may have to look to white birch a replacement for yellow birch in cross-banding and cores.

The ratios of the cut to the inventory would not be so alarming if our cruises of the area showed that the stands of the future could be cut in the came proportions. Unfortunately they do not. Material in Age Class II, which would be our next cut, is made up predominantly of hard maple. This means that for the near future the prospects for yellow birch do not look good. Nor does the distant future look any better. Our present cutting system in the hardwood-that is, a light selection cut-does not favor the reproduction of yellow birch; instead it encourages the maple by reducing competition from the birch.

At Swan Lake in Peck Township (Algonquin Park Area) the Division of Research of the Ontario Department of Lands and Forests have, since 1950 , been studying the principal causes of the failure of yellow birch to ro-establish itself.

The list as compiled by their research foresters is as follows:

(1) The undisturbed leaf litter in stands selectively cut during the winter, and in uncut stands, restricts the seed germination.

(2) The present-day cut in tolerant hardwood stands is so light that the crown canopy remains closed. This results in unsatisfactory height growth of the birch seedlings which do germinate.

(3) Due to insufficient height growth during the first years, the seedlings are finally smothered by the second and subsequent fall of leaves.

(4) The light cut in hardwood stands favors the re-establishment of hard maple which is severe competition for yellow birch.

(5) In areas where the deer population is excessive, continuous browsing may very well become the controlling factor in birch seedling survival.

Evidence of where some of these causes have been removed proves that they are on the right track.

This past summer our company opened up an old railway spur for a road and all along the old right-of-way which had been opened up and scarified some 40 or more years ago there was exceptional yellow birch young growth.

Another instance is around old mines where fuelwood was taken and thus a heavy cut was made in a small area, we have noted the predominance of yellow birch in the regeneration.

Looking at more recent cut-overs on our limits, we have seen evidence of good height growth in birch only 4 or 5 years old along the roads where the canopy was opened up sufficiently, whereas along the skidding trails, the scarification was enough for seed germination but there was not enough light for height growth and the seedlings are not developing.

This would tend to indicate that our present logging methods do not go far enough in encouraging reproduction. Tractor skidding and tree length 
logging are being practiced, it is true, but much of this logging is done in the winter with snow on the ground and thus the leaf litter remains undisturbed. More summer and fall logging would do much to assist nature.

In addition to this we may have to do a little extra work beyond actual logging by widening out the skid trails and removing some of the nonmerchantable trees in order to open up the canopy.

Portable mills would do much toward utilizing these lower grades and thus enable a heavier cut to be made.

Much of the future of our present stands of birch is dependent upon better utilization in the bush. A great deal of veneer grade birch is wasted by improper cutting of the logs. Closer supervision and training of cutters is necessary if we are to extract the high quality logs necessary to maintain veneer production at its increasing tempo.

Something else which cannot be overlooked in the bush and that is the teaching of the bush worker to respect the young growth which will be our birch of to-morrow. At present few have any regard for young birch when selecting their skidways or when cutting their skids. Whatever is handiest and of the right size they will use.

Once the cutter has done his job there is still the problem of careless grading in the log yard. Far too often veneer logs are lost to the sawmill through lack of skilled scalers.

Even after the $\log$ reaches the veneer mill, constant and expert supervision is necessary if we are to prevent unnecessary waste of this valuable species. Improper treatment in the steam vats can cause end splitting of the logs which in turn means waste at the clippers.

In the jointing and splicing operations of the veneer mill, there is an opportunity for increased utilization in the proper use of the right machine. New equipment should be studied, for anything that will increase our efficient use of the present supply of yellow birch will do much to insure the future of birch in the veneer industry.

In conclusion I would say that, although we have reason to be somewhat pessimistic about the future of birch, nevertheless, there is some hope. There is some volume in the size class just under merchantability at present, and although the volume per acre for the next cut will be smaller, there should be better quality since the overmature trees will be gone. In addition, where permanent road systems have been developed the cost of extraction will be less and even the lower volumes will be economically merchantable.

In my own area, Sault Ste. Marie, the hardwood bush has gone undisturbed by logging for many years and there has been some regeneration so that $\mathbf{l}$ feel even our present logging will help to increase this. In addition, research has shown how we can improve upon this, and if we are willing to invest a little in the future of yellow birch there should be a crop for the next generation.

Machinery, methods and men's knowledge can be improved upon, and if we can grow the raw material, then I feel the mills will be able to utilize it better, assuring a future for the veneer industry. 